\title{
Alat Musik Perkusi Di Asia Tenggara (Sebuah Kajian Arkeomusikologi)
}

\section{Peter Ferdinandus}

Keywords: musical instrument, archaeology, analogy, artifact, classic, Hindu-Buddha

\section{How to Cite:}

Ferdinandus, P. Alat Musik Perkusi Di Asia Tenggara (Sebuah Kajian Arkeomusikologi). Berkala Arkeologi, 15(3), 215-217. https://doi.org/10.30883/iba.v15i3.697

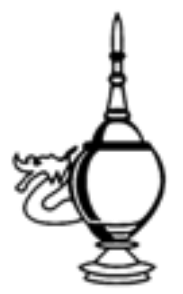

\section{Berkala Arkeologi}

https://berkalaarkeologi.kemdikbud.go.id/

Volume 15 No. 3, 1995, 215-217

DOI: $10.30883 /$ jba.v15i3.697

\section{c) (1) 8 (2)}

This work is licensed under a Creative Commons Attribution-NonCommercialShareAlike 4.0 International License. 


\title{
ALAT MUSIK PERKUSI DI ASIA TENGGARA (Sebuah Kajian Arkeomusikologi)
}

\author{
Peter Ferdinandus \\ (Pusat Penelitian Arkeologi Nasional)
}

\section{Pendahuluan}

Penelitian mengenai musik dalam arkeo-logi seiama ini masih dirasa kurang diminati, ka-rena sifatnya yang abstrak. Peninggalan musik sering menjadi pertanyaan apakah data berupa visual seperti relief dapat berbunyi?. Sebagai aki-batnya data aspek musik kurang diperhatikan. Misalnya dengan ditemukan nakara perunggu berbentuk genderang di Asia Tenggara pada per-mulaan abad ke-19 M. Perhatian para sarjana Eropa pada masa itu hanya pada bentuk, deko-rasi dan fungsi.

Tahun 1897 A.B.Meyer dan W.Foy mengklasifikasikan nakara, dan tahun 1902 dilanjutkan oleh F. Heger. Di Indonesia seperti di jawa, Sumatra, Bali sampai ke arah timur didapatkan nakara. Penemuan benda-benda tersebut mendapat perhatian khusus dari Van Der Hoop dan dilanjutkan para arkeolog lainnya seperti Van Heekeren, R.P.Soejono dan D.D.Bintari.

Dari hasil pengamatan kami ternyata perhatian para arkeolog umumnya terpusat pada bentuk, dekorasi dan fungsi. Sedangkan nakara sebagai alat musik kurang mendapat perhatian. Sebab jika diperhatikan yang terpenting dari sebuah nekara bukanlah dekorasi tetapi bunyi yang dihasilkan (Ferdinandus 1994).

Nakara sebagai alat musik mulai diperhatikan oieh Jaap Kunst (1927) tetapi ia tidak banyak membicarakan mengenai nakara. Musik berhubungan dengan bunyi dan dikenal sejak manusia hidup. Lingkungan manusia selalu diliputi oleh bunyi yang kemudian dimanfaatkan manusia. Meskipun musik adalah abstrak tetapi benda atau artefak sehubungan dengan musik ditemu-kan baik dalam penggalian maupun survei.

Masalah pertama yang timbul adalah apakah mungkin penelitian musik dalam arkeologi ini dilaksanakan arkeolog ataukah para musikologi? Sebab obyek penelitian arkeologi adalah budaya materi dan merupakan produk kegiatan sosial. Kegiatan itu tidak dapat langsung diamati dari pengamatan kebudayaan sosial. Meskipun demikian penelitian musik dalam arkeologi termasuk penelitian budaya.

Apabila permasalahan ini diterapkan dalam permasalahan musik, maka permasalahannya akan lebih jelas. Misalnya Heger menyusun teori tentang bentuk dan kemudian sarjana-sarjana lainnya mengenai fungsi, tetapi tidak mengetahui latar belakang alat musik tersebut.

Seperti dijelaskan oleh Noerhadi Magetsan (1994:4) secara operasional arkeologi merupakan ilmu yang mengkaji artefak ditinjau dari demensi bentuk (formal), waktu (temporal) dan tempat (spatial). Tinjauan proses tidak dapat secara langsung dikaji faktanya sebab telah musnan Noerhadi menjelaskan data arkeologi sebagai nasil observasi mutunya tergantung dari pengetanuan, pengalaman, dan ketajaman peneliti dalam melakukan observasi. Oleh sebab itu para arkeolog harus rinci menyampaikan proses observas yang dilakukannya sehingga dapat diterapkan oleh orang lain seandainya menerapkan proses yang sama. Berdasarkan pada minimnya konseptual, metodologis dan penerapannya maka datam kertas kerja ini akan diuraikan solusı mengatas। metode penelitian musik arkeologi

Pertama seorang peneliti harus mengenal pengertian musik. Definisi musik hingga akhirakhir ini sering menjadi permasalahan. Arti musik sering didefinisikan sebagai arti yang sempit. Menurut Meyer (1956) ada tiga kesalahan fatal yang dilakukan oleh para peneliti psikologi seperti Wundt, Stumpf dan psikolog lainnya. Pertama musik didasarkan pada suatu perasaan menyenangkan. Kedua golongan atomism berpendapat musik sebagai deretan bunyi terdiri dan bunyi yang mempunyai ciri tersendiri dan bunyi yang kompleks. Ketiga para penganut universalis berpendapat semuanya universal. Unsur bunyi yang menyenangkan dan tidak menyenangkan adatah tidak universal harus dipelajari dan dialami. Tiap bangsa mempunyai rasa bunyi yang menyenang. kan dan tidak menyenangkan. Oleh sebab itu musik tidak universal. Harus dipelajari untuk mengenal musik dari suatu suku bangsa. Sebagai contoh orang Cina senang akan musik Cina mengatakan musik Eropa buruk demikian pula sebaliknya. Itu terjadi jika mereka tidak memahami dan mempelajari musik itu sendiri.

Berdasarkan pada hal tersebut di atas, maka para musikolog dan sarjana-sarjana lain yang mengetahui musik berpendapat musik mempunyai makna (meaning). Musik mempunyai hubungan erat dengan bunyi. Suatu bunyi atau beberapa bunyi mempunyai yang arti bagi si pendengar adalah unsur musik. Oleh sebab itu musik 
terdırı darı satu atau beberapa nada (Meyer 1956) Seperti telah dikemukakan pada Rapat Analisis Sumber Tertulis Masa Klasik di Trowulan (1991) manusia sejak lahir memiliki akal pikiran yang digunakan untuk menciptakan alat dan kemudian menjadi teknologi. Dalam kehidupan semua bagian alam suatu sistem berinteraksi satu sama lain baik dengan sesama maupun antar mahkhluk hidup dan benda mati. Kegiatan manusia dalam mengolah sumberdaya alam sejak masa prasejarah bukan saja flora - fauna dan mineral, tetapi bunyi aiam yang dihasilkan lingkungannya. Bunyi ada yang kuat, lembut, tinggi dan rendah, berasal dari sumber bunyi yang digetarkan oleh suatu tenaga manusia, angin, air dan sebagainya. Dengan adanya unsur-unsur tersebut terjadilah teknologi sumber-sumber bunyi angin, anggota tubuh manusia, logam atau bahan lain.

Pendapat di atas senada dengan pendapat Gasya Lund (1993) yang menyatakan adanya kebutuhan bunyi melahirkan berbagai macam alat bunyi-bunyian yang berkembang menjadi musik. Bunyi didapatkan dari pengalaman hidup manusia Mesir, Mesopotamia, Yunani, India dan Cina sebelum tarikh masehi yang menghasilkan perkembangan teori dan alat musik dari bangsabangsa yang belum mengenal tulisan. Oleh sebab itu melalui metode analogi melalui etnoarkeologi perlu diterapkan. Analogi yang dimaksudkan adalah antara prosesual kebudayaan masa lampau dengan prosesual kebudayaan yang masih ada sekarang.

Dalam tulisan Ini akan diuraian alat-alat musik perkusi di Asia Tenggara sebelum pengaruh budaya Hindu dan masa Jawa Kuno dengan pendekatan prasasti. naskah, relief, etnografi serta ekperimen

\section{Alat-alat Musik Perkusi}

Data arkeologi berupa alat musik perkusi di Asia Tenggara pada permulaan tarikh masehi adalah Nakara atau Kettledrum. Dari tulisan saya (1984) dan Bernet Kempers (1986) dijelaskan dari segi musikologi nakara merupakan alat musik perkusi (pukul) dan termasuk jenis Ideofon(1)

Alat musik ini ditemukan juga di Indonesia baik dari hasil survei maupun penggalian. Bentuk alat ini mengingatkan bentuk genderang golongan membranofon. Alat musik ini hingga kini ma-sih dipergunakan oleh masyarakat Karen di Asia Tenggara sehingga dapat diketahui cara memainkannya.

Alat musik ini dimainkan dalam berbagai cara yaitu digantungkan atau diletakan di atas permukaan tanah dengan disanggah sesuatu benda supaya rongga alat musik tersebut tidak tertutup. Cara memainkannya dengan memukul tongkat dan mengores jari kuku. Pertama dipukul dengan lambat, dari pinggir ke tengah dan makin cepat (Marshall, 1929). Sistem bermainnya sama dengan kendang bercelah (slit Drum) (Berne! Kempers, 1986). Bunyi yang dihasilkan ritme getaran dengungannya seperti gong. Di Thailand aiat musik ini masih dipergunakan dalam upaca-ra menanam padi.

Dari uraian tersebut menunjukkan ritme memegang peranan penting. Selain itu bentuk gendrang golongan membranofon menjadi golongan ideofon menunjukkan masa itu teori bunyi d Asia Tenggara cukup tinggi. Sejarah alat musik gendrang menunjukkan yang berbahan kayu dan kulit lebih tua dari yang berbahan perunggu (Sach,1941:25-40). Perkembangan teknologı dsebabkan karena adanya kebutuhan akan bunyl (Ferdi-nadus 1994).

Pada masa prasejarah bunyi merupakan unsur penting dalam komunikasi dengan arwah nenek moyang dalam upacara ritus. Bunyi dianggap memiliki unsur kekuatan alam (Sachs 1962) Penelitian para sarjana menunjukkan bahwa fungsi nakara adalah lambang kepala suku, sedangkan motif dekorasinya mempunyai arti simbolik (Bernet Kempers 1986)

Dikenalnya alat musik perkusi sebagai aia: musik utama pada masa itu menimbulkan pertanyaan mengapa musik petik atau musik tiup tidak mempunyai peranan penting?. Padahal nekara berbentuk besar dan berbunyi keras. sementara alat tiup atau petik relatif kecil dan praktis. Selain itu bunyi yang dihasilkan menyebabkan reaksi emosi tertentu dari pendengarnya. Bunyi lembut memberi respon tenang. Sedangkan bunyi gemuruh menjadikan orang kaget dan takut (Meyer 1956:22). Dari hasil penelitian jenis alat musik pukul atau perkusi seperti kendang dan gong yang berbunyi monoton mempunyai peranan pen-ting bagi syaraf seorang. Bunyi tersebut dapat mempengaruh syaraf seseorang sedemikian rupa hingga mencapai satu titik tidak sadar (Rouget 1980:245-248).

Contoh kasus, musik metal atau rock menyebabkan anak-anak muda menjadi histeris dan melakukan pengrusakan. Dari pengamatan kami, bunyi keras dan monoton dapat mengakibatkan seorang mencapai trans dan histeris.

Dengan adanya trans dalam upacara keagamaan dan permainan reog, kuda kepang. musik mempunyai peranan penting. Dari hasil pengamatan kami di Jawa dan Bali bunyi nitme yang dihasilkan oleh alat musik perkusi mempe-ngaruh: jiwa seseorang.

Uraian tersebut di atas menunjukkan sebelum pengaruh Hindu-Buddha di Indonesia. masyarakatnya telah mengenal dasar teori buny! se- 
cara lisan yaitu bunyi yang didapatkan dari pengalaman. Dengan masuknya pengaruh HinduBuddha yang telah maju dalam seni musik dan diperkenalkan alat-alat musik baru seperti wina, lute, harpa, trompet (dari hasil pengamatan kami di relief-relief, naskah dan prasasti), alat musik pukulperkusi tetap mendapat perhatian dan berperan penting (Ferdinandus 1993 dan 1994).

Hasil penelitian Deva (1980) musik India bersifat melodis dan mereka mengenal berbagai jenis raga, tetapi unsur ini tidak mempengaruhi musik di Indonesia. di Indonesia juga telah mengenal tangga nada slendro dan pelog. Legende rakyat, naskah Natyasatra menjelaskan raga didapatkan dari dewa Siwa. Tetapi di Indonesia (Jawa) dikenal dewa Siwa memberi tangga nada slendro dan bukan raga (Ferdinandus, 1994).

Dalam memperkaya musik Indonesia tidaklah sepenuhnya mengambil semua unsur musik dari India dan Cina, tetapi melalui seleksi. Masuknya pengaruh Hindu-Buddha, Cina, dan Arab tidak merubah konsep dasar alat musik Asia Tenggara. Alat musik perkusi tetap memegang peranan penting sedangkan pengaruh luar memperkaya jenis alat musik perkusi. Hal ini terlihat dengan perpindahan pusat kerajaan Mataram ke Jawa Timur dengan adanya alat-alat musik yang tidak dikenal sebelumnya.

Perpindahan pusat kerajaan Jawa Kuno dari Jawa Tengah ke Jawa Timur pada abad ke 10 terlihat dari naskah-naskah alat musik perkusi golongan ideofon seperti gending, salunding, gong, gambang dan simbal(ideofon) dan golongan membranofon seperti jenis kendang memegang peranan penting meskipun alat-alat musik melodis lainnya seperti suling, lute, siter, dan celempung dikenal pada masa itu (Ferdinandus 1994).

\section{Penutup}

Data arkeologis berupa relief bangunan di Indonesia (Borobudur, Prambanan, Panataran) dan Asia Tenggara (Angkor Vat, Bakong, dan Bayong) menunjukkan bahwa alat musik seperti gong, kendang, bonang, dan gambang dikenal di Asia Tenggara seperti Indonesia, Malaysia, Thailand, Laos, Vietnam, Burma, Kamboja dan Burma. Hingga kini alat musik tersebut dipergunakan dalam upacara keagamaan maupun hiburan

Dari uraian tersebut didapatkan kesimpulan bahwa dasar alat musik di Asia Tenggara bersifat perkusi menjadi dasar perkembangan instrumentalis tradisional di Indonesia. Sehubungan de-ngan uraian tersebut di atas menunjukkan aspek musik sudah waktunya masuk dalam studi arkeologi.

\section{KEPUSTAKAAN}

Deva,BC.1980, Ancient Indian Musical Instruments of India New-Delhi.

Ferdinandus,Peter.1986. Beberapa Tinjauan Mengenai Pelog Dan Siendro, kertas kerja da. lam Rapat Evaluasi Hasil Penelitian Arkeologi li, 1984.

Ferdinandus,Peter,1991.Beberapa Alat Musik Pada Masa Jawa Kuna. Sebuah Kajian Arkea musikologi, dalam Rapat Analisis Sumber Tertulis Masa Klasik Trowulan

Ferdinandus, Peter. 1993. Musical Instruments in Indonesia during the $|X-X|$ Century A.D. Actes du Xlle Congrs International des Sciences Prehistoriques et Protohistoriques, Bratisalva, 1-7 September 1991.

Ferdinandus,Peter.1994.,Ancient Javanese musical Instruments: Origin and development. Euroupean Association of Southeast Asian Archaeologists 5th International Conference, is MEO - Paris.

Kempers, Bernet.A.J., 1986/1987."Kettledrums of Southeast Asia." dalam Modern Quarternary Research in Southeast Asia 10

Kunst, Jaap.1949. The Cultural background of Indonesian Music. Amsterdam. Royal institute for the Tropicsa: 6, pls. 10-13

Lund,Gajsas.1993. Underground Music, An Archaeomusicological Introduction to the Bronze Shields (CA.700B.CO Found at Froslunda in Sweden. Actes du Xlle Congres International des Sciences Prehistoriques et Protohistoriques, Bratislava, 1-7 septembe 1991

Marshall,HI. 1929. Karen bron drums Joumal Burma Research Society 19(1):1-14.

Meyer,Leonard B.1956. Emotion and Meaning London

Noerhadi,Magetsari.1995. Metode Penelitian Agama Dalam Arkeologi Dibawakan dalam Seminar Nasional Metodologi Riset Arkeologi. Depok: FS-UI

Rouget,Gilbert.1980. La Musique et la Transe Gallimard. 